$\S=-1$ 圆

\title{
Urban Agriculture Program: the Intention of Participants to Remain As Volunteers
}

\author{
Leelanayagi Ramalingam ${ }^{1}$, Juwaidah Sharifuddin ${ }^{2 *}$, Zainal Abidin Mohamed ${ }^{3}$, Fazlin Ali $^{4}$ \\ ${ }^{1,2,3,4}$ Department of Agribusiness and Bioresource Economics, Universiti Putra Malaysia, Selangor, Malaysia \\ *Corresponding author E-mail: juwaidah@ upm.edu.my
}

\begin{abstract}
Community Garden Program is a program where people from a residential area practice urban agriculture together in a common place. Production of crop and livestock within cities is known as urban agriculture. Community Garden Program is one of the most popular initiatives by the Malaysian government in enhancing urban agriculture. Nevertheless, the program is facing challenges in attracting and retaining the volunteers. This article aims to identify the association between socio-eco-demographic characteristics and intention to remain as a volunteer for Urban Agriculture Program. The survey was conducted among 375 volunteers in Klang Valley using questionnaire. Descriptive analysis, reliability analysis and chi-square test for independence analysis were conducted. The result from descriptive analysis shows that most participants have the intention to remain as volunteers. The Cronbach's Alpha test specified that the internal consistency of intention to remain items was excellent. Chi-square test for independence indicated that elder male with high income is more likely to remain as volunteers for the Urban Agriculture Program. This study expands the existing literature on volunteerism among the urban dweller regarding participating in community-based Urban Agriculture Program.
\end{abstract}

\section{Introduction}

Overpopulation is a phenomenon where the environmental resources are unsuccessful in fulfilling individuals needs such as shelter and nutrition when the threshold of population density is exceeded (1). By the year 2050, the world population is anticipated to reach 9.1 billion, and about $70 \%$ of the population will be concentrated in urban areas (2). Overpopulation leads to increase in human consumption level and depletion of resources such as food, energy and raw materials. Consequently, the price of food, energy and raw material throughout the supply chain will increase tremendously. Additionally, this phenomenon also might cause environmental problems in terms of disposal of urban wastes and wastewater. With a greater amount of population living in the urban regions, the unemployment rate in the cities will be high and leads to urban poverty. One of the ways to overcome problems of overpopulation is urban agriculture. UNDP (1996) interpret urban agriculture as food and fuel industry which predominantly a response to the urban dwellers' needs by utilizing rigorous production techniques, natural resources and urban wastes, to produce a variety of crops and livestock.

There are some countries that have successfully practising urban agriculture. In Netherland, for instance, urban agriculture is aided by the Resources Center on Urban Agriculture and Food Security (RUAF) Foundation by giving training, policy lobby, technical support action-research, plan in the area of urban agriculture and urban food action plan as well as legal advocacy (3). In the same token, Dutch Ministry of Agriculture equally adopts the abstraction of urban agriculture in its policy document on Sustainable Food. The goal of Urban Agriculture Program is Gezonde Gronden (Healthy Soil) in the city of Hague is to let the citizens of west
Netherland to enjoy the produced food in their areas. The city dwellers gain knowledge on sustainable food production through the arranged courses which teach them to reinforce the agroecosystem's productive capacity without the inputs of chemical and closing the water and nutrient cycles. Other Dutch cities also have similar initiatives (4).

Thailand is an example of a country which actively entailed in urban agriculture. The Thailand urban agriculture was practised since the $19^{\text {th }}$ century. Currently, its Department of Agriculture has established the "Garden in Honour of Her Royal Highness Princes Sirindhorn" which provides people living in, as well as surrounding Bangkok with training, continuous technical support, seeds/seedlings and agricultural tools. Similarly, Bangkok Metropolitans' Urban and Peri-urban Agriculture (UPA) support an onroof and vertical urban farming. Thai City Farm Project (CFP), on the other hand, is one of the non-government organizations that encourage urban and rural people to run UPA. CFP is now running in 96 communities, which includes crop production in gardens at homes, schools, hospitals, prisons and on vacant public lands (5) (6).

In China, the concept of urban agriculture was introduced in the 1990s, after identifying the significance of urban agriculture to preserve urban evolution. The development of urban agriculture in China was contributed by the policies on rural-urban integration and sustainable development (7). An official program was launched by Beijing's municipality in order to inspire multifunctional urban agriculture in peri-urban regions by assisting the establishment of "agro-parks", that provide food, used as educational tools and as a tourism attraction. Five zones were created to regulate the categories of agro-parks in the town. The "inner urban core" priorities on gardening, exhibition and landscaping; the "inner suburban plain" distinctive in precision agriculture and recreational agriculture; the "outer suburban plain" highlight on 
contemporary agricultural production with huge scale; the "mountainous" zone dedicated to ecologic conservation; and the "regional cooperation" zone aids strengthen food security (8).

The success stories of urban agriculture in other countries lead Malaysian government to launch Green Earth Campaign in 2006 and Urban Agriculture Campaign in 2014 in attempts to introduce urban agriculture among its urban dwellers. Community Garden Program is a type of urban agriculture which is practised by residents of housing areas such as flats, apartments and terrace houses together at a common idle space in their residential areas. Activities related to Urban Agriculture Program include open fertigation, conventional or organic garden (9). This Urban Agriculture Program is supported by local authorities, Ministry of Agriculture and Agro-Based Industry Malaysia (MOA), Universiti Putra Malaysia (UPM) and Malaysian Agriculture Research and Development Institute (MARDI). Residential areas included in the Urban Agriculture Program, among others, are Kota Kemuning, Shah Alam; Lim Garden, Ipoh; Taman Springhill, Seremban; and Taman Desa Damai, Pulau Pinang (9).

Even though Urban Agriculture Program in Malaysia is supported by the government organizations especially MOA, few challenges has made the sustainability of Urban Agriculture Program a question mark. The challenges were in attracting and retaining volunteers for the program. According to the Senior Deputy Director of Putrajaya Corporation Landscape and Parks Development, Noriah Mat, the participation in every Community Gardens should be at least $25 \%$, but at its highest point, the participation is only $11 \%$, and in a year it has decreased to nearly $5 \%$. Hence, the dropout rate of volunteers from Urban Agriculture Program in Putrajaya is almost half (The Star, 2014). Therefore, this research is to scrutinize the intention of volunteers to remain and continue as volunteer in the Urban Agriculture Program set up by the government.

\section{Literature Review}

According to (10) intention is an instant determinant of behavior. A proper gauge of intention is able to offer the most precise forecast of behavior. In the study of (11), they divided intentionto-remain into three categories as they deduced that people have contrasting interest when asked to evaluate the likelihood of sustaining volunteer for non-profit organization for 6 months (short-term), 1 year (medium term) and 2 years (long-term). The current study measures the intention to remain in Urban Agriculture Program as volunteers. Hence, the definition of intention-toremain in this study is "the belief of volunteers that they will continue to be volunteering in Urban Agriculture Program as long as the program is being held or organize by respective government agencies or NGOs" (12). The intention to remain as a volunteer for Urban Agriculture Program was measured in terms of general (in the future), medium term (next year) as well as long-term (five years).

(13) conducted study about commitment and future volunteering intention at biking race events. They included education level, income level, age and gender in the correlation analysis with the intention to remain to volunteer. The results showed that education level, income level and age correlated positively and significantly with the future volunteering intention. This indicates that younger volunteers with a lower education and income level are less likely to volunteer at the future bike racing events.

In (14) in their study of environmental volunteers' motivations, included gender, race and age as independent variables which predict the intentions to volunteer in the future for the same organization and also different organization. Gender, race and age were significant predictors of future volunteering intention for the same organization. Moreover, the findings imply that both female and male who are white with age below 35 years old and above 65 years old tend to remain as a volunteer for the same organization. However, none of the socio-demographic variables was a significant predictor of intention to volunteer in the future for different organizations.

(15) study time and money volunteering among older adults. In terms of time, adults aged between 55-64 who have a high level of education and have income level below $\$ 5,000$, have intention for future volunteering. In terms of money, adults aged below 55 years old who are widowed/divorced/separated with high education and income level of more than $\$ 5,000$ intended for future volunteering.

(16) also conducted research on intention to volunteer in terms of giving time and money. A young female who possess high education level with previous volunteering experience intends to volunteer by giving their time. The same group of people also intends to volunteer by giving their money. The finding was similar as (15) wherein both researches indicated that highly educated people tend to volunteer.

(17) found that age is a significant predictor of volunteer retention in non-profit organizations. Elder volunteers intended to remain as volunteers. The finding was similar to (18). He found that older volunteers intended to stay with the non-profit sports organization. Nevertheless, the finding of (19) differed where a volunteer who aged between 16-24 years old are most likely to have the intention to volunteer in future events.

(20) studied on the motivation of sport mega-event volunteers and intention to volunteer for post-event. The result of binary logistic regression analysis indicated that age, as well as previous volunteering experiences, significantly influenced the likelihood of respondents to volunteer in the post events. Additionally, the odd ratios of age and previous volunteering experiences suggest that elder volunteers with volunteering experiences are less likely to volunteer more in the future. However, (19) found that experienced female volunteers are most likely to have the intention to volunteer in future events. Additionally, they also found that volunteers with low-income level tend to be continuing volunteer in the future.

(21), in their study of employee volunteering: A review and framework for future research, found that age, gender, education and responsibility for children were the most commonly studied demographic antecedents of volunteering. Volunteering increases with age; men are less likely to volunteer as compared to women; higher education level is associated with greater volunteering and child-rearing responsibilities tend to exhibit more volunteering.

\section{Methodology/Materials}

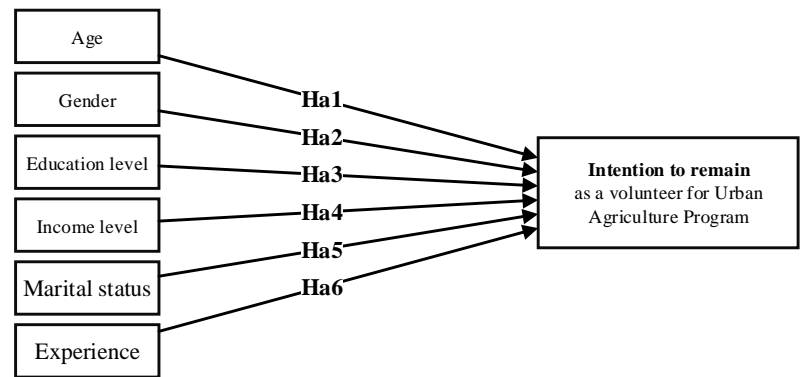

Fig. 1: Association between Socio-eco-demographic Characteristics and Intention to Remain as Volunteer for Urban Agriculture Program

Based on the previous research and their findings, it is hypothesized that volunteers' socio-demographic profile would have an association with their intention to remain as a volunteer for Urban Agriculture Program. Socio-demographic characteristics which were included in the present study were age, gender, education level, income level, marital status and experience. More specifically, the following alternative hypotheses are developed:

$\mathrm{H}_{\mathrm{A}} 1$ : There is an association between age and intention to remain as a volunteer for Urban Agriculture Program. 
$\mathrm{H}_{\mathrm{A}}$ 2: There is an association between gender and intention to remain as a volunteer for Urban Agriculture Program.

$\mathrm{H}_{\mathrm{A}} 3$ : There is an association between education level and intention to remain as a volunteer for Urban Agriculture Program.

$\mathrm{H}_{\mathrm{A}} 4$ : There is an association between income level and intention to remain as a volunteer for Urban Agriculture Program.

$\mathrm{H}_{\mathrm{A}}$ 5: There is an association between marital status and intention to remain as a volunteer for Urban Agriculture Program.

$\mathrm{H}_{\mathrm{A}}$ 6: There is an association between experience and intention to remain as a volunteer for Urban Agriculture Program.

Community Garden Program is a type of urban agriculture activity that is carried out by people from the same residential area together at a common place. Hence, the study population is anyone who is practising urban agriculture in a community-based program. The focus of the research is community-based Urban Agriculture Program in Klang Valley. Therefore, volunteers from Klang Valley Urban Agriculture Program were approached for data collection. The population of the volunteers was unknown. According to (22) at 95 percent confident level, 384 sample sizes are able to represent a total population of 500 million. Hence, four hundred and two (402) questionnaires were distributed, and 390 usable questionnaires were collected with a response rate of $97 \%$. After preliminary analysis, a total of 375 responses were used to be analyzed using descriptive analysis, reliability analysis and chisquare test for independence. Descriptive analysis was employed to explore and summaries the collected raw data. Reliability analysis was applied to assess the internal consistency of scale. The Cronbach's Alpha was used as an indicator of internal consistency. Lastly, chi-square test for independence was utilized to find out the association between socio-eco-demographic characteristics and intention to remain as a volunteer for Urban Agriculture Program.

\section{Results and Findings}

\subsection{Descriptive analysis of Volunteers' Socio- demographic Characteristics}

Table 1: Volunteers Profile

\begin{tabular}{|c|c|c|}
\hline Characteristic & Frequency (n) & Percentage (\%) \\
\hline Age (years old) & & \\
\hline $20-29$ & 23 & 6.1 \\
\hline $30-39$ & 67 & 17.9 \\
\hline $40-49$ & 107 & 28.5 \\
\hline $50-59$ & 126 & 33.6 \\
\hline
\end{tabular}

\begin{tabular}{|l|c|c|}
\hline 60 or older & 52 & 13.9 \\
\hline Gender & & 45.9 \\
\hline Male & 172 & 54.1 \\
\hline Female & 203 & \\
\hline Education level & & 7.2 \\
\hline Primary education & 27 & 57.6 \\
\hline Secondary education & 216 & 35.2 \\
\hline Tertiary education & 132 & \\
\hline Employment status & & 13.9 \\
\hline Not working & 52 & 13.9 \\
\hline Retired & 52 & 21.6 \\
\hline Housewife & 81 & 10.4 \\
\hline Government sector & 39 & 40.3 \\
\hline Private Sector & 151 & \\
\hline Income & & 72.0 \\
\hline Less than RM2500 & 270 & 21.6 \\
\hline RM2500 - RM5000 & 81 & 6.4 \\
\hline More than RM5000 & 24 & 10.7 \\
\hline Marital status & & 89.3 \\
\hline Single & 30 & \\
\hline Married & 335 & 78.7 \\
\hline $\begin{array}{l}\text { Experience in Urban Agri- } \\
\text { culture Program }\end{array}$ & & 1.9 \\
\hline Less than 2 years & 295 & \\
\hline 2-3 years & 73 & \\
\hline More than 3 years & 7 & \\
\hline Table 1 shows the distibution &
\end{tabular}

Table 1 shows the distribution of respondents' socio-demographic profile as described by frequency distribution and percentage share of the distribution. Based on Table 1, it shows that the greatest number of the respondents were female aged between 50 to 59 years old. About fifty-eight percent $(58 \%)$ of the volunteers had education until secondary school, and forty percent (40\%) of the volunteers work in private sector. Majority of them had a salary below RM2,500, were married and possessed less than 2 years of experience in Urban Agriculture Program.

\subsection{Descriptive Analysis of Intention-to-Remain Items}

Table 2 shows the result of descriptive analysis for items used to measure intention to remain as a volunteer for Urban Agriculture Program. About $90 \%$ of the volunteers mentioned that they intend to remain as a volunteer for Urban Agriculture Program for next year and in the future. Approximately $88 \%$ of the volunteers indicate that they intend to remain as a volunteer in Urban Agriculture Program for five years.

Table 2: Frequency Distributions for Intention to Remain Items

\begin{tabular}{|c|c|c|c|c|c|c|c|c|c|}
\hline \multirow{2}{*}{ Statement } & \multicolumn{7}{|c|}{ Percentage (\%) } & \multirow{2}{*}{ Mean } & \multirow{2}{*}{$\begin{array}{l}\text { Standard } \\
\text { deviation }\end{array}$} \\
\hline & 1 & 2 & 3 & 4 & 5 & 6 & 7 & & \\
\hline $\begin{array}{l}\text { I intend to remain as a volunteer in Urban } \\
\text { Agriculture Program in the future }\end{array}$ & 0.3 & 0.0 & 2.7 & 7.2 & 25.9 & 34.1 & 29.9 & 5.80 & 1.056 \\
\hline $\begin{array}{l}\text { I intend to remain as a volunteer in Urban } \\
\text { Agriculture Program for the next year }\end{array}$ & 0.0 & 0.3 & 2.1 & 7.5 & 22.9 & 35.2 & 32.0 & 5.87 & 1.033 \\
\hline $\begin{array}{l}\text { I intend to remain as a volunteer in Urban } \\
\text { Agriculture Program for five years }\end{array}$ & 0.3 & 0.3 & 2.1 & 9.1 & 26.1 & 33.1 & 29.1 & 5.76 & 1.078 \\
\hline AVERAGE & & & & & & & & 5.81 & 1.056 \\
\hline
\end{tabular}

*Indicators: 1: "strongly disagree" to 7: "strongly agree"

Table 2 also illustrates that respondents intend to remain as a volunteer in Urban Agriculture Program for the next year (5.87) had the highest mean value followed by in the future (5.80) and for five years (5.76). The average mean value of 5.81 is suggesting that most of the respondents possess positive intention to remain as a volunteer for Urban Agriculture Program.

\subsection{Reliability Analysis of Intention to Remain As Vol- unteers in Urban Agriculture Program}

The Cronbach's Alpha of intention to remain as a volunteer for Urban Agriculture Program is 0.913 which indicates that the intention to remain items had adequate internal reliability consistency. The rule of thumb for Cronbach's Alpha is $\alpha \geq 0.9$ is excellent; 0.9 $>\alpha \geq 0.8$ is good; $0.8>\alpha \geq 0.7$ is acceptable; $0.7>\alpha \geq 0.6$ is questionable; $0.6>\alpha \geq 0.5$ is poor; and $0.5<\alpha$ is unacceptable (23). Based on the rule of thumb, the value of Cronbach's Alpha reported here is excellent. 


\subsection{Chi-Square Test for Independence}

A chi-square test for independence with Yates continuity correction for $2 \times 2$ contingency table was carried out to discover the association between socio-demographic characteristics of volunteers and their intention to remain as a volunteer for Urban Agriculture Program. Table 3 presents the coding system applied to the independent variables of the analysis.

Table 3: Socio-demographic Characteristics Variables used in Chi-square Test for Independence

\begin{tabular}{|l|l|}
\hline Variables & Coding systems \\
\hline Age & $0:$ Less than 49 years old (younger) \\
& $1: 49$ years old and above (elder) \\
\hline Gender & $0:$ Male \\
& 1: Female \\
\hline Education level & 0: Primary and secondary education (low) \\
& 1: Tertiary education (high) \\
\hline Income level & 0: Below RM1500 (low) \\
& 1: RM1500 and above (high) \\
\hline Marital status & 0: Single \\
& $1:$ Married \\
\hline Experience & $0:$ Below 9 months (low) \\
& $1: 9$ months and above (high) \\
\hline
\end{tabular}

The outcome of chi-square test for independence with Yates continuity correction is as shown in Table 4 . The results indicated that there were significant association between age group $\left[\chi_{\text {yates }}^{2}(1, n\right.$ $=375)=8.12, \mathrm{p}<0.05, \mathrm{phi}=0.15]$, gender $\left[\chi^{2}\right.$ yates $(1, \mathrm{n}=375)=$ $9.48, \mathrm{p}<0.05$, phi $=-0.17]$, income level $\left[\chi_{\text {yates }}^{2}(1, \mathrm{n}=375)=\right.$ $5.21, \mathrm{p}<0.05, \mathrm{phi}=0.12]$ and intention to remain as volunteer for Urban Agriculture Program. However, education level $\left[\chi^{2}\right.$ yates $(1, \mathrm{n}$ $=375)=0.62, \mathrm{p}>0.05, \mathrm{phi}=0.05]$, marital status $\left[\chi_{\text {yates }}^{2}(1, \mathrm{n}=\right.$ $375)=0.00, \mathrm{p}>0.05, \mathrm{phi}=0.00]$ and experience $\left[\chi_{\text {yates }}^{2}(1, \mathrm{n}=\right.$ $375)=0.04, p>0.05, \mathrm{phi}=0.02]$ were not significantly associated with intention to remain as volunteer for Urban Agriculture Program. The results also indicated that male volunteers who were elder and had high income level were more likely to remain as volunteer for Urban Agriculture Program.

Table 4: Cross Tabulation of Socio-eco-demographic Characteristics and Intention to Remain as Volunteer for Urban Agriculture Program

\begin{tabular}{|c|c|c|c|c|}
\hline \multirow{2}{*}{$\begin{array}{c}\text { Socio-eco- } \\
\text { demographic } \\
\text { Characteristics }\end{array}$} & \multicolumn{2}{|c|}{ Intention to remain } & \multirow[b]{2}{*}{$\chi_{\text {Yates }}^{2}$} & \multirow[b]{2}{*}{ Phi (Ф) } \\
\hline & No & Yes & & \\
\hline \multicolumn{5}{|l|}{ Age Group } \\
\hline Younger & 147 & 38 & \multirow{2}{*}{$8.12 *$} & \multirow{2}{*}{0.15} \\
\hline Elder & 125 & 65 & & \\
\hline \multicolumn{5}{|l|}{ Gender } \\
\hline Male & 111 & 61 & \multirow{2}{*}{$9.48^{*}$} & \multirow{2}{*}{-0.17} \\
\hline Female & 161 & 42 & & \\
\hline \multicolumn{5}{|l|}{ Education level } \\
\hline Low & 180 & 63 & \multirow{2}{*}{0.62} & \multirow{2}{*}{0.05} \\
\hline High & 90 & 40 & & \\
\hline \multicolumn{5}{|l|}{ Income } \\
\hline Low & 146 & 41 & \multirow{2}{*}{$5.21 *$} & \multirow[b]{2}{*}{0.12} \\
\hline High & 126 & 62 & & \\
\hline \multicolumn{5}{|l|}{ Marital status } \\
\hline Single & 29 & 11 & \multirow{2}{*}{0.00} & \multirow{2}{*}{0.00} \\
\hline Married & 243 & 92 & & \\
\hline \multicolumn{5}{|l|}{ Experience } \\
\hline Low & 129 & 47 & \multirow{2}{*}{0.04} & \multirow{2}{*}{0.02} \\
\hline High & 143 & 56 & & \\
\hline
\end{tabular}

The finding of the chi-square test for independence with Yates continuity correction is summarized in Table 5.
Table 5: The Summary of Findings

\begin{tabular}{|c|c|c|}
\hline \multicolumn{2}{|r|}{ Hypotheses } & Decision \\
\hline $\mathrm{H}_{\mathrm{A}} 1:$ & $\begin{array}{l}\text { There is an association between age and } \\
\text { intention to remain as a volunteer for Urban } \\
\text { Agriculture Program. }\end{array}$ & Supported \\
\hline $\mathrm{H}_{\mathrm{A}} 2:$ & $\begin{array}{l}\text { There is an association between gender and } \\
\text { intention to remain as a volunteer for Urban } \\
\text { Agriculture Program. }\end{array}$ & Supported \\
\hline $\mathrm{H}_{\mathrm{A}} 3:$ & $\begin{array}{l}\text { There is an association between education } \\
\text { level and intention to remain as a volunteer } \\
\text { for Urban Agriculture Program. }\end{array}$ & $\begin{array}{c}\text { Not support- } \\
\text { ed }\end{array}$ \\
\hline $\mathrm{H}_{\mathrm{A}} 4:$ & $\begin{array}{l}\text { There is an association between income } \\
\text { level and intention to remain as a volunteer } \\
\text { for Urban Agriculture Program. }\end{array}$ & Supported \\
\hline $\mathrm{H}_{\mathrm{A}} 5:$ & $\begin{array}{l}\text { There is an association between marital } \\
\text { status and intention to remain as a } \\
\text { volunteer for Urban Agriculture Program. }\end{array}$ & $\begin{array}{c}\text { Not support- } \\
\text { ed }\end{array}$ \\
\hline $\mathrm{H}_{\mathrm{A}} 6:$ & $\begin{array}{l}\text { There is an association between experience } \\
\text { and intention to remain as a volunteer for } \\
\text { Urban Agriculture Program. }\end{array}$ & $\begin{array}{c}\text { Not support- } \\
\text { ed }\end{array}$ \\
\hline
\end{tabular}

\section{Conclusion}

The research objective is to inspect the association between sociodemographic characteristics and intention to remain as volunteers for Urban Agriculture Program by using descriptive analysis, reliability analysis and chi-square test for independence analysis. Descriptive analysis showed that most of the volunteers have the intention to remain as volunteers for Urban Agriculture Program in the future. This indicates that the Urban Agriculture Program is able to resume future success with the support of current volunteers. The finding of reliability analysis of intention to remain as a volunteer for Urban Agriculture Program suggests that the items can be used for future volunteerism studies which measure intention-to-remain. Moreover, the result of the chi-square test for independence indicated that elder male volunteers with high-income level are more likely to remain as volunteers for Urban Agriculture Program. Hence, the recruitment of volunteers will be favorable if government organization chooses to promote Urban Agriculture Program among elder male with high income.

\section{References}

[1] OECD. Overpopulation 2001. Available from: https://stats.oecd.org/glossary/detail.asp?ID=1978.

[2] FAO. How to feed the world in 2050 2009. Available from: http://www.fao.org/fileadmin/templates/wsfs/docs/expert_paper/Ho w_to_Feed_the_World_in_2050.pdf

[3] RUAFFoundation. About RUAF 2017. Available from: http://www.ruaf.org/about-ruaf

[4] Schans JWV. Urban Agriculture in the Netherlands. Urban Agriculture Magazine. 2010:40-2.

[5] Suteethorn K, editor Urban Agriculture: Ecological Functions for Urban Landscape. The IFLA APR Conference; 2009; Incheon, South Korea.

[6] Linwattana G, editor Application of horticulture in improving urban and peri-urban agriculture towards enhancing food production in Bangkok city. Regional Workshop of Strengthening Urban \& Periurban Agriculture towards Resilient Food Systems in Asia; 2013 28th -30th 2013; Bangkok, Thailand. Bangkok: FAO.

[7] Zhu X. Planning for urban agriculture in China: Wageningen University; 2016.

[8] Jianming C. Urban agriculture makes China's cities more liveable $2014 . \quad$ Available from: https://www.chinadialogue.net/article/show/single/en/7091-Urbanagriculture-makes-China-s-cities-more-liveable

[9] MOA. Urban agriculture 2015. Available from: http://www.doa.gov.my/pertanian-bandar.

[10] Ajzen I, Fishbein M. Understanding Attitudes and Predicting Social Behavior. Upper Saddle River, N.J.: Prentice-Hall; 1980.

[11] Jimenez MLV, Fuertes FC, Abad MJS. Differences and Similarities among volunteers who drop out during the first year and volunteers who continue after eight years. The Spanish Journal of Psychology. 2010;13(1):343-52. 
[12] Elstad B. Continuance commitment and reasons to quit: A study of volunteers at a jazz festival. Event Management. 2003;8(2):99-108.

[13] Mykletun RJ, Himanen K. Volunteers at biking race events: antecedents of commitment and intention to remain volunteering at future events. Sport, Business and Management: An International Journal. 2006;6(3):1-44.

[14] Stukas AA, Worth KA, Clary EG, \& Snyder, M. The matching of motivations to affordances in the volunteer environment. Nonprofit and Voluntary Sector Quarterly. 2009;38(1):5-28.

[15] Choi NG, Chou RJ. Time and money volunteering among older adults: the relationship between past and current volunteering and correlates of change and stability. . Ageing and Society. 2010;30:559-81.

[16] Bekkers R. Who gives what and when? A scenario study of intentions to give time and money. Social Science Research. 2010;39(3):369-81.

[17] Garner JT, Garner LT. Volunteering an opinion: Organizational voice and volunteer retention in non-profit organizations. Nonprofit and Voluntary Sector Quarterly. 2010;20(10):1-16.

[18] Bang H. Volunteer age, job satisfaction and intention to stay. Leadership \& Organization Development Journal. 2015;36(2):16176.

[19] Alexander A, Kim SB, Kim DY. Segmenting volunteers by motivation in the 2012 London Olympic Games. Tourism Management. 2015;47:1-10.

[20] Dickson TJ, Darcy S, Edwards D, Terwiel FA. Sport mega-event volunteers' motivations and postevent intention to volunteer: The Sydney World Master Games, 2009. Event Management. 2015;19:227-45

[21] Rodell JB, Breitsohl H, Schroder M, Keating DJ. Employee volunteering: A review and framework for future research. Journal of Management. 2015;20(10):1-30.

[22] Krejcie RV, Morgan DW. Determining sample size for research activities. Educational and Psychological Measurement. 1970;30:607-10.

[23] George D, Mallery P. SPSS for Windows step by step: A simple guide and reference 11.0 update 4ed. Boston: Allyn \& Bacon; 2003. 